УдК 330.658 .87

T. I. Олійник,

к. е.н., дочент, кафедри економіки, підприємничтва та управління підприємствами, Аніпровський начіональний університет імені Олеся Гончара, м. Аніпро

Н. В. Кривичька, магістр, Аніпровський начіональний університет імені Олеся Гончара, м. Аніпро

DOI: $10.32702 / 2306-6814.2018 .22 .66$

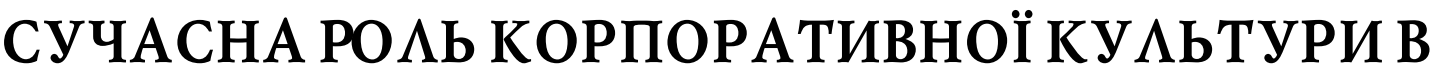

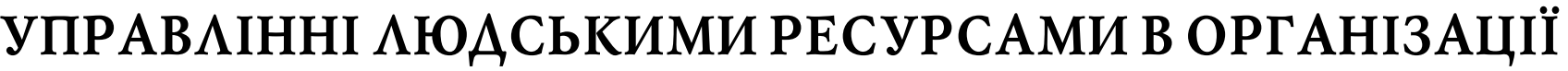

\author{
T. Oliynyk, \\ Ph.D, associate professor of economics, entrepreneurship and enterprise management, \\ National University Oles Honchar, Dnipro \\ N. Krivitskaya, \\ master, National University Oles Honchar, Dnipro
}

\section{MODERN ROLE OF CORPORATE CULTURE IN THE MANAGEMENT OF HUMAN RESOURCES IN THE ORGANIZATION}

Устаттірозкрито сутність і поняття "корпоративна культура", зокрема на ряду економічної, управлінської, соціологічної і психологічної позиції в тлумаченніцього поняття, окреслено різноманітні підходи до її визначення та надано авторське трактування. Визначено особливості вітчизняних підходів до дефініції поняття "корпоративна культура". Встановлено, що більшістьз механізмів корпоративної культури вдіяльності вітчизняних організацій практично не використовується, особливо це стосується державних підприємств. Досліджено вплив корпоративної культури надіяльність організації та управління людськими ресурсами, де корпоративна культура в основному розуміється як набір норм, правил, традицій, що приймаються менеджментом і персоналом організації, якіотримують вираз уцінностяхщозаявлені організацією, у орієнтирах поведінки і дій, що задані персоналу. Окреслено ключові функції організацій, що мають міцну корпоративну культуруі в той же час існуючі проблеми впровадження корпоративної культури у діяльність вітчизняних організацій. Сформульовано чинники, які визначають потребу вітчизняних організацій узміні корпоративної культури, а саме вплив корпоративної культури на показники діяльності організації та на якість управління людськими ресурсами, що зумовлює необхідність існування ефективної корпоративної культури, робить доцільним процес її формування та удосконалювання. Визначено, щозавдяки удосконаленню та оновленню існуючої корпоративної культури, керівництво організації може досягти намічених результатів як для окремого структурного підрозділу, так і для організації в цілому.

The article reveals the essence and concept of "corporate culture", in particular on a number of economic, managerial, sociological and psychological positions in the interpretation of this concept, outlines various approaches to its definition and provides author's interpretation. The features of domestic approaches to the definition of the concept "corporate culture" are determined. It is established that most of the mechanisms of corporate culture in the activity of domestic organizations are practically not used, especially in the case of state-owned enterprises. The influence of corporate culture on the activity of organization and management of human resources, where corporate culture is basically understood as a set of norms, rules, traditions, accepted by the management and personnel of the organization that receive the expression in the values declared by the organization, in the guidelines of behavior and actions given the staff. The main functions of organizations with a strong corporate culture and, at the same time, existing problems of corporate culture introduction into the activities of native organizations are outlined. Formulated factors that determine the need for domestic organizations to change the corporate culture, namely, the impact of corporate culture on the performance of the organization and the quality of human resources management, which necessitates the existence of an effective corporate culture, makes the process of its formation and improvement expedient. It is determined that due to the improvement and updating of the existing corporate culture, the management of the organization can achieve the intended results both for a separate structural unit and for the organization as a whole.

Ключові слова: корпоратиВна культура, організачія, підприємстВо, управління, людськіресурси, колективний договір, підприємницьке середовище, стимулювання, інтеграція.

Key words: corporate culture, organization, enterprise, management, human resources, collective bargaining, entrepreneurial environment, promotion, integration.

\section{ПОСТАНОВКА ПРОБАЕМИ}

Сучасний етап розвитку ринкових відносин в Україні характеризується загостренням конкурентної боротьби між господарюючими суб'єктами. Подібні тенденції змушують підприємства різних організаційних фрорм окрім фрінансових ресурсів, шукати й інші ефрективні методи підвищення конкурентоспроможності, у тому числі і через підвищення ефективності управління. Од- 


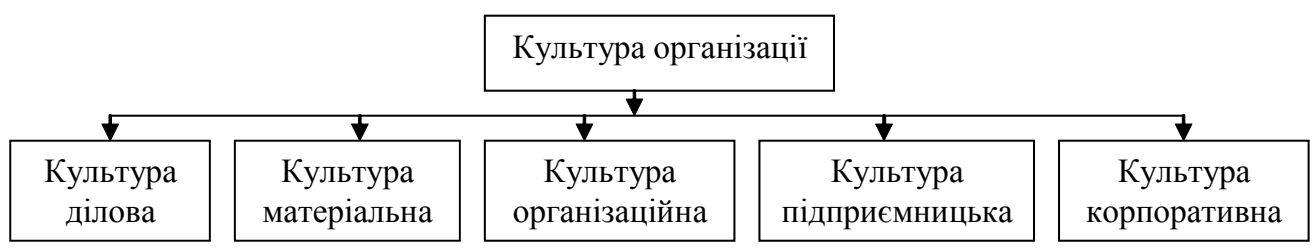

Рис. 1. Складові системи культури в організації

Джерело: [10].

ним з таких ключових механізмів "нефрінансового" підвищення конкурентоспроможності підприємства $€$ розвиток корпоративної культури.

\section{АНА $\Lambda$ З АОС $А$ АЖЕНЬ І ПУБАІКАЦІЙ}

Вагомим внеском у розвиток наукових досліджень корпоративної культури є праці Дж. Грейсона, К. О'Делла, П. Друкера, В. Оучі та ін. Серед вітчизняних дослідників проблематикою корпоративної культури займалися О. Балика, В. Близнюк, О. Комарова, О. Левченко, І. Терон та інші.

Високо оцінюючи проведені дослідження та не принижуючи їх значення, необхідним $є$ виявлення впливу корпоративної культури на діяльність організації та управління людськими ресурсами.

\section{МЕТОЮ АОС АІАЖЕННЯ}

Метою дослідження $є$ вироблення підходів щодо функціонування корпоративної культури з урахуванням специфріки вітчизняних умов ринкового господарювання.

\section{ВИКААА ОСНОВНОГО MATEPIA $\Lambda$ У}

Корпоративна культура присутня у будь-якій організації і виникає з моменту її створення. Водночас чітке визначення поняття "корпоративної культури" в організації викликає певні труднощі, оскільки існує декілька різноспрямованих точок зору на це питання.

Зокрема можна констатувати безліч визначень корпоративної культури на ряду економічної, управлінської, соціологічної і психологічної позиції в тлумаченні цього поняття. Так культура в організації може бути представлена як система, що включає в себе інші підсистеми (рис. 1).

Саме виділення підсистем культури організації дозволяє нам виокремити корпоративну культуру, для якої існують різні дефрініційні авторські визначення в її трактуванні (табл. 1).

Авторські трактування суті корпоративної культур $\epsilon$ досить різноманітними та різноспрямованими, і проаналізувавши наведені тлумачення, відзначимо, що поняття корпоративної культури в основному розуміється як набір норм, правил, традицій, що приймаються менеджментом і персоналом організації, які отримують вираз у цінностях, що заявлені організацією, у орієнтирах поведінки і дій, що задані персоналу.

Слід зазначити, що незважаючи на значну кількість досліджень з проблематики розвитку корпоративної культури, здійснених зарубіжними фрахівцями, необхідним сьогодні $\epsilon$ напрацювання поглядів на корпоративну культуру, зумовлених специфікою української економіки.
Виходячи з того, що для кожного підприємства властива корпоративна культура, яка здійснює вплив на його діяльність, окреслюється внутрішнім середовищем, а саме: корпоративна культура складається 3 цінностей підприємства, цінностей працівників, правил і норм які формують поведінку персоналу та забезпечують порядок в їх роботі. Здійснюючи при цьому вплив на діяльність підприємства, роблять її ефективною, забезпечують максимальне задоволення особистих інтересів управлінців, працівників та контрагентів підприємства в т.ч. і держави.

Саме вплив корпоративної культури на показники діяльності організації та на якість управління людськими ресурсами, зумовлює необхідність існування ефективної корпоративної культури, робить доцільним процес ії̈ формування та удосконалювання. Внаслідок чого виділяють п'ять фракторів організації, яка має міцну корпоративну культуру [8]:

1. Усвідомлення міцності фрінансового стану організації з чітким баченням напрямів і шляхів ії̈ розвитку.

2. Наявність механізму стимулювання та вдосконалення профресіоналізму співробітників.

3. Заохочення високої якості праці.

4. Розвинута система соціального захисту співробітників.

5. Гнучкі форми ефективної, індивідуальної і колективної роботи.

При цьому необхідно зазначити, кожній організації притаманні особливі, властиві тільки для неї цінності, стиль ведення бізнесу, фрілософрія, принципи, правила і норми поведінки. Це елементи корпоративної культури, а отже, корпоративна культура в кожній організації матиме свої, властиві лише їй особливості.

Сьогодні українські підприємства активно розвивають свою корпоративну культуру. Так, наприклад, все частіше проводяться різноманітні тренінги, конференції, корпоративні вечори. Це вже є першим кроком до впровадження формалізованої корпоративної культури. Найбільші підприємства намагаються фрормувати корпоративну культуру із використанням провідного світового досвіду: різноманітних тренінгів персоналу, корпоративного сайту, дощок оголошень з пропозиціями та найцікавішими листами співробітників [9].

Окремо слід визначити, що більшість з механізмів корпоративної культури в діяльності вітчизняних організацій практично не використовується. Особливо це стосується державних підприємств. Так, наприклад, сучасне державне підприємство "Документ" - широко відома мережа центрів обслуговування громадян "Паспортний сервіс" - незважаючи на декларовану сучасність у своїй діяльності користується обмеженими ат- 
Таблиця 1. Основні дефініції "корпоративна культура"

\begin{tabular}{|c|c|}
\hline Трактування визначення & Автор \\
\hline $\begin{array}{l}\text { Корпоративну культуру можна визначити як сферу менеджменту, пов’язану з розвитком } \\
\text { інтеграційних процесів в управлінні, яка включає в якості основних компонентів цінності членів } \\
\text { трудового колективу організації, переконання, норми поведінки і комунікаційної взаємодії } \\
\text { працівників в процес трудової діяльності, елементи матеріального середовища і тим самим } \\
\text { відображають індивідуальність даної організації }\end{array}$ & Ю. Бугаєвська [4] \\
\hline $\begin{array}{l}\text { Це сукупність прийнятих на даному підприємстві норм і правил поведінки по відношенню до } \\
\text { клієнтів і партнерів, а також культура міжособових стосунків на підприємстві. Це - втілення «духу } \\
\text { компанії», коли всі співробітники - від керівників до виконавців - чітко усвідомлюють завдання } \\
\text { компанії і прикладають максимум зусиль для їх реалізації }\end{array}$ & I. Терон [12] \\
\hline $\begin{array}{l}\text { Це сукупність правил, звичаїв та сталої практики в галузі корпоративного управління, яка не } \\
\text { отримала нормативного закріплення в законодавстві та базується на загальному культурному рівні } \\
\text { суспільства, нормах моралі, діловій практиці тощо. Культуру організації можна визначити як } \\
\text { сукупність ідей, корпоративних цінностей і норм поведінки, що формуються в ході спільної } \\
\text { діяльності для досягнення загальних цілей певної організації }\end{array}$ & Т. Бєляк [3] \\
\hline $\begin{array}{l}\text { Корпоративна культура - це є соціальний ресурс концептуально оформлених ідей, цінностей, } \\
\text { відносин, очікувань, способу мислення, норм і правил поведінки, традицій та корпоративної } \\
\text { символіки, що формуються в ході спільної діяльності для досягнення цілей організації }\end{array}$ & О. Балика [2] \\
\hline $\begin{array}{l}\text { Це система цінностей, вірувань, переконань, уявлень, очікувань, символів, а також ділових } \\
\text { принципів, норм поведінки, традицій ритуалів і т.д., які склалися в організації або ії підрозділах за } \\
\text { час діяльності та приймаються більшістю співробітників }\end{array}$ & М. Семикіна [11] \\
\hline $\begin{array}{l}\text { Під корпоративною культурою розуміється встановлена система уявлень, символів, норм, цінностей } \\
\text { і прикладів поведінки, що сприймаються всіма членами корпорації }\end{array}$ & I. Петрова [8] \\
\hline $\begin{array}{l}\text { Є сукупністю ціннісних установок, норм, формальних та неформальних законів поведінки, які } \\
\text { відбивають соціальні, економічні, виробничі відносини, що склалися в корпорації та культивуються } \\
\text { iї керівництвом }\end{array}$ & Н. Гриценко [5] \\
\hline $\begin{array}{l}\text { Невидиме і неформальне «усвідомлення» організації - образ думок, управлінська культура (ідеологія } \\
\text { управління, стилі керівництва і вирішення керівниками проблем, їх поведінка загалом), яка визначає } \\
\text { політику організації по відношенню до працівників, партнерів і клієнтів; сукупність найбільш } \\
\text { важливих ідей, поглядів, основних цінностей і стандартів, переконань, етичних норм, вірувань і } \\
\text { очікувань, які приймають більшість працівників }\end{array}$ & О. Апостолюк [1] \\
\hline
\end{tabular}

рибутами корпоративної культури, чим недосконало реалізує свій потенціал [7].

Головним документом, який містить основи корпоративної культури державного підприємства "Документ", є Колективний договір, та якщо оцінювати існуючу корпоративну культуру за її трирівневою структурою, то вона реалізована здебільшого на "поверхневому" або "символічному" рівні і майже не розвинута на другому ("глибшому") та третьому ("глибинному") рівнях. Для державного підприємства "Документ" на перший план повинно виходити внутрішньоорганізаційні, внутрішньокультурні та фріліальні чинники потреби в зміні корпоративної культури. Тому звичайно доцільним $є$ групування функцій корпоративної культури, виходячи з їх змістовного наповнення, щоб сорормувати системний підхід до її перетворення, це [6]:

- перша група фрункцій - фрормування поведінки працівників;

- друга група - інформаційного забезпечення та реагування в управлінні людськими ресурсами;

- третя група - збереження цінностей та передача досвіду;

- четверта група - полегшення систем управління організацією;

— п'ята група — стимулювання, інтегрування та розвитку працівників.

Отже, можна зробити висновок, що державне підприємство "Документ" потребує формалізації та трансорормації існуючої корпоративної культури у бік інноваційної корпоративної культури, як найбільш ефективного на сучасному етапі зразка корпоративної культури.

У цьому випадку представимо основні зовнішні та внутрішні чинники впливу, які на наш погляд визнача- ють потребу державного підприємства "Документ" у становленні корпоративної культури за окремими її напрямами:

1. Чинники зовнішнього середовища - обмеження посередників у вигляді приватного сервісу які, наприклад, надають паспортні послуги, де відбувається зростання попиту внаслідок отримання безвізового режиму, і не мають на це законних підстав, а оформлення документу відбувається через Центр надання адміністративних послуг (ЦНАП).

2. Чинники внутрішньоорганізаційного середовища впровадження інноваційних технологій (біометричні паспорти), де останнім часом запроваджено сучасну послугу виїзного обслуговування громадян, що також потребує відповідних змін у корпоративній культурі.

3. Внутрішньокультурні чинники - подолання протиріч між двома корпоративними субкультурами офрісної (головного офрісу в м. Києві) та агентської (відділів у містах України).

4. Внутрішньоагентські чинники - можливість виконання поставлених завдань між головним офісом та реальними можливостями територіальних відділів у їх виконанні; інформаційний обмін між співробітниками головного офрісу та відділів у містах; оперативність управління відділом та ефективність контролю.

Таким чином, корпоративна культура відіграє значну роль у діяльності організації, отже, керівництво повинне бути зацікавленим та компетентним у сфері впровадження, оцінювання, розвитку, удосконалення та фрінансування корпоративної культури.

\section{ВИСНОВКИ І ПЕРСПЕКТИВИ ПОАААЬШИХ РОЗВІАОК}

Культура $є$ невід'ємною частиною суспільства, незалежно від епохи. А в наш час, особливо коли відбу- 
вається інтенсивний розвиток ринкової економіки, потреба в розумінні сутності та значення корпоративної культури постає пріоритетним чинником розвитку будь-якої організації. Сьогодні недостатньо переймати досвід успішних зарубіжних підприємств, слід виробляти та впроваджувати власні підходи до корпоративної культури з урахуванням вітчизняної специфріки економічного середовища та управлінських засад.

Значна кількість вітчизняних організацій на сучасному етапі потребує удосконалення існуючої корпоративної культури у зв'язку зі значними змінами зовнішнього підприємницького середовища, а також через істотну невизначеність. До цього також можна віднести і проблему інформаційного обміну на різних рівнях управління. Зокрема інформація, що надходить до головного офісу від фрілії, може бути спотворена або односторонньо надана, в такому разі можуть прийматися неправильні стратегічні, фрінансові і кадрові рішення. Тому завдяки удосконаленню та оновленню існуючої корпоративної культури, керівництво організації може досягти намічених результатів як для окремого структурного підрозділу, так і для організації в ціломy.

\section{Література:}

1. Апостолюк О. Корпоративна культура як інструмент ефективного менеджменту підприємства в підвищенні його конкурентоспроможності / О. Апостолюк // Економічний часопис Східноєвропейського національного університету імені Лесі Українки. - 2016. № 2. - С. 68-73.

2. Балика О.Г. Стратегічне управління корпоративною культурою / Балика О.Г. / / Науковий вісник Полтавського університету економіки і торгівлі: Економічні науки. - 2011. - № 4 (49). - С. 195-200.

3. Беляк Т.А. Корпоративная культура в условиях трансформаций социально-трудовых отношений в Украине / Т.А. Беляк // Азимут научных исследований: экономика и управление. - 2014. - № 3. С. $10-12$.

4. Бугаєвська Ю.В. Поняття корпоративної культури: її суть і структура / Ю.В. Бугаєвська // Засоби навчальної та науково-дослідної роботи. - 2011. № 36. - С. $12-17$.

5. Гриценко Н.В. Особливості фрормування корпоративної культури організації / Н.В. Гриценко / / Вісник економіки транспорту і промисловості. - 2017. № 59. - C 284-290.

6. Новосад М.Г. Корпоративна культура підприємств в контексті сучасних європейських стандартах, 2013 р. - [Електронний ресурс] / М.Г. Новосад - Режим доступу: http://lib.pu.if.ua.

7. Офіційний сайт ДП "Документ", 2014 р. - [Електронний ресурс]. - Режим доступу: https://pasport.org.ua

8. Петрова І.Л. Вплив корпоративної культури на модернізацію соціально-трудових відносин / І.Л. Петрова // Вчені записки. - 2015. - № 40. - С. 139145.

9. Пушкар 3.М. Корпоративна культура в контексті діяльності організації / З.М. Пушкар, Д.В. Панчук //
Молодий вчений - 2017. - № 10 (50). - С. 10251028.

10. Семикіна М.В. Діагностика впливу корпоративної культури на стан соціально-трудових відносин / М.В. Семикіна, Т.О. Беляк / / Соціально-трудові відносини: теорія та практика: зб. наук. пр. - 2015. — № 2 (10). - С. 54-63.

11. Семикіна М.В. Корпоративна культура та якість людського капіталу: особливості взаємовпливу / М.В. Семикіна, Т.О. Бєляк // Наукові праці Кіровоградського національного технічного університету. Економічні науки. - 2015. - № 28. - С. 68-75.

12. Терон І.В. Корпоративна культура в механізмах регулювання соціально-трудових відносин / І.В. Терон / / Глобальні та національні проблеми економіки. 2015. - № 6. - С. 639-643.

\section{References:}

1. Apostoliuk, O. (2016), "Corporate culture as an instrument of effective management of the enterprise in increasing its competitiveness", Ekonomichnyj chasopys Skhidnoievropejs'koho natsional'noho universytetu imeni Lesi Ukrainky, vol. 2, pp. 68-73.

2. Balyka, O.H. (2011), "Strategic management of corporate culture", Naukovyj visnyk Poltavs'koho universytetu ekonomiky i torhivli: Ekonomichni nauky, vol. 4 (49), pp. $195-200$.

3. Beliak, T.A. (2014), "Corporate culture in the conditions of transformation of social and labor relations in Ukraine", Azymut nauchnykh yssledovanyj: ekonomyka y upravlenye, vol. 3, pp. 10-12.

4. Buhaievs'ka, Yu.V. (2011), "Concept of corporate culture: its essence and structure", Zasoby navchal'noi ta naukovo-doslidnoi roboty, vol. 36, pp. 12-17.

5. Hrytsenko, N.V. (2017), "Features of formation of corporate culture of organization", Visnyk ekonomiky transportu i promyslovosti, vol. 59, pp. 284-290.

6. Novosad, M.H. (2013), "Corporate culture of enterprises in the context of modern European standards", Retrieved from http://lib.pu.if.ua

7. The official site of the "Document". (2014), Retrieved from https://pasport.org.ua

8. Petrova, I.L. (2015), "Influence of corporate culture on modernization of social and labor relations", Vcheni zapysky, vol. 40, pp. 139-145.

9. Pushkar, Z.M. (2017), "Corporate culture in the context of the organization's activities", Molodyj vchenyj, vol. $10(50)$, pp. 1025-1028.

10. Cemykina, M.V. and Beliak, T.O. (2015), "Diagnosis of the influence of corporate culture on the state of social and labor relations", Sotsial'no-trudovi vidnosyny: teoriia ta praktyka: zb. nauk. pr., vol. 2 (10). pp. 54-63.

11. Cemykina, M.V. and Beliak, T.O. (2015), "Corporate culture and quality of human capital: features of mutual influence", Naukovi pratsi Kirovohrads'koho natsionaI'noho tekhnichnoho universytetu. Ekonomichni nauky, vol. 28 , pp. $68-75$.

12. Teron, I.V. (2015), "Corporate culture in the mechanisms of regulation of social and labor relations", Hlobal'ni ta natsional'ni problemy ekonomiky, vol. 6, pp. $639-643$.

Стаття надійшла до редакції 27.10.2018 p. 